\title{
At forstå (folke)biblioteket
}

\section{Anmeldelse af Matthias Engberg Eiriksson}

Andersen, J, Jochumsen H, Rasmussen CH (red.) (2008): At forstå biblioteket. En introduktion til teoretiske perspektiver. København: [S.l.]: Danmarks Biblioteksforening. 267 s. ISBN 978-87-90849-53-5

Biblioteksvidenskaben er ikke en enhedsvidenskab. Man kan vel snarere tale om biblioteksvidenskaber, der forandrer sig både efter den optik, man anlægger, og efter hvad man iagttager. Danmarks Biblioteksskole og Danmarks Biblioteksforening har taget initiativ til at udgive en antologi, der viser en del af bredden af den danske biblioteksforskning. Det er der kommet et godt produkt ud af, og det skal de have stor ros for.

Bogen er opdelt $i$ tre hoveddele med hver sin synsvinkel på biblioteksvidenskab. Den første del handler om biblioteket som stedet, hvor brugeren møder materialet, hvad enten det er i form af skønlitteratur, film, billeder, Internettet eller tekst i meget bred forstand. De fire bidrag i denne kategori kommer omkring genreteori - både den klassiske skønlitterære genreteori, som den kommer til udtryk i bøger og film - og i en nyere udgave, hvor genre ses som en samfundsskabt måde at agere tekstligt; billedteori, hvor grænsen mellem billede og skrift dekonstrueres og sættes sammen på nye måder samt receptionsteori, der handler om den meningsdannelse, der konstituerer mødet mellem læser og tekst.

Matthias Engberg Eiriksson, Danmarks Statistik, Bibliotekoginformation, eirixon@gmail.com
Anden del behandler forholdet mellem biblioteket og samfundet. Der er altså tale om en mere sociologisk orienteret vinkling, der kommer omkring Bourdieus begreber habitus, social og kulturel kapital samt felt; institutionel teori, der bl.a. forklarer hvorfor mennesker og organisationers handlinger ikke nødvendigvis kan forklares rationelt; oplevelsessamfundet, der ikke er helt så nyt som mange tror - men som er en kommende udfordring for bibliotekerne og kulturel læring, der sætter bibliotekets rolle som bærer af integrationsprocesser i perspektiv.

Sidste del sætter et historisk fokus på biblioteket. Dels gennem en præsentation af Foucaults teorier omkring magt og viden; dels gennem en gennemgang af bibliotekets rolle som hukommelsesinstitution - en hukommelsesinstitution, der selv er en del af historien, og derfor kan behandles gennem forskellige historiefaglige optikker.

Hvert bidrag består af en præsentation af det pågældende teoriområde og derefter eksempler på, hvorledes det relaterer sig til biblioteksfeltet. Bogen kommer således vidt omkring, og man er i ordets bedste betydning blevet belært, når man vender sidste side.

\section{Medier, tekst og bruger}

Claus Secher behandler i sit bidrag fiktionsgenrer som kommunikationsformer, klassifikationsredskaber og fortolkningsredskaber. Genrer er tekster, der grupperes sammen på baggrund af slægtskab. Imidlertid er der ikke enighed om, hvad der konstituerer 
en genre, ligesom den kulturelle smag, der vurderer genrernes kvalitet også ændrer sig. At der er et hierarki mellem genrerne er der dog ikke tvivl om. I den løbende debat om bogen og bibliotekerne er netop dette et af stridspunkterne. Skal biblioteket være et eksklusivt sted med fokus på den gode smag og den smalle litteratur eller skal man snarere søge en profil, der lægger vægt på populærlitteraturen.

Genreteori bliver også behandlet i Jack Andersens bidrag, men her set i lyset af retorik. Her bliver genrer ikke til nogle bestemte træk ved tekster, men derimod udtryk for de sociale handlinger en tekst udfører i en given sammenhæng. En genre er i denne forståelse en typificeret retorisk handling, der er baseret på tilbagevendende situationer. Dette løft af abstraktionsniveau gør det muligt at analysere tekster i mere bred forstand, fx internethjemmesider, databaser eller online communities.

Hans Dam Christensen kommer i et stramt skrevet bidrag omkring både Merleau-Pontys fænomenologi, Gadamers hermeneutik og semiotik og dekonstruktion ved både Peirce, Saussure, Derrida, Barthes m.fl. Emnet er billeder og visuel kompetence, altså evnen til at aflæse et billedes betydningsniveauer - i modsætning til bibliotekets traditionelle fokus på skrifttænkning.

Receptionsteori, som er emnet for Gitte Ballings bidrag, handler om mødet mellem tekst og modtager. Tekster er i udgangspunktet flertydige, hvilket skaber rum for modtagerens fortolkning. Det er denne fortolkningsproces, der er i fokus. Alt efter tilgang kan denne meningsdannelse ses mere eller mindre afhængigt af henholdsvis teksten, læseren og de fortolkningsfællesskaber, læseren er en del af.

\section{Institution, samfund $0 \mathrm{~g}$ forandring}

Henrik Jochumsen og Casper Hvenegaard Rasmussen introducerer Bourdieus. Habitus er Bourdieus begreb for de værdi- og normsystemer, kulturelle vaner eller holdningssystemer, der styrer vores adfærd. Sammen med vores kulturelle og økonomiske kapital forklarer det vores praksis i et givet felt. For eksempel kan man bruge begreberne til at analysere forskellige grupperingers brug (eller ikke-brug) af folkebiblioteket ud fra, hvorledes de placerer sig i det sociale rum, der udgøres af akserne kulturel/økonomisk kapital og samlet mængde kapital.
Nanna Kann-Christensen gennemgår i sit bidrag begrebet institutionel teori, der drejer sig om at forklare organisationers handlemåde. Organisationers handlinger kan ikke forklares efter den klassiske rationalitet. Der er snarere tale om, at organisationer følger en logik, der handler om, hvad der fremstår som passende, det der kan legitimere organisationen - det er først bagefter at man rationaliserer beslutningerne.

Casper Hvenegaard Rasmussen og Henrik Jochumsen skriver om biblioteket i oplevelsessamfundet. Biblioteket er både en indirekte formidler af oplevelser, fx gennem de materialer, der lånes ud og en direkte formidler af oplevelser. Selve biblioteksbes $\varnothing-$ get kan være en oplevelse, både qua sin arkitektur eller materialeopstilling, men også gennem aktiviteter på biblioteket som $\mathrm{fx}$ oplæsninger eller dukketeater. Der er gennem de senere år kommet stor fokus på de økonomiske aspekter af kulturlivet, men selve idéen med biblioteker som oplevelsesgeneratorer stammer tilbage fra biblioteksloven fra 1964 og før det indførelsen af de åbne hylders princip.

Biblioteket som mødested for forskellige kulturer behandles af Camilla Moring og Hans Elbeshausen. Bibliotekets selvforståelse er ændret fra at være et symbol på dansk kultur til at være et frirum for integration. En del af dette arbejde med integration går gennem kulturel læring, der handler om at nærme sig det ukendte ved langsomt at flytte grænsen mellem det kendte og det fremmede. Dette kan ske gennem læring i praksisfællesskaber, som socialisering gennem fortællinger og gennem deltagelse i dialog.

\section{Bibliotekshistorie, viden og historiekultur}

Laura Skouvigs bidrag om Foucault stiller spørgsmålet om folkebibliotekets danske historie på en ny måde. Frem for at se historien i lyset af store begivenheder og store skikkelser kigges der i stedet på tilblivelsen af begrebet folkebibliotek og de mulighedsbetingelser, der gjorde sig gældende i den periode mellem 1900 og 1920, da monumentet "folkebibliotek" rejste sig. Der er således tale om en mere sociologisk tilgang til historien, hvor idéen om det handlende subjekt sættes i baggrunden til fordel for en undersøgelse af de diskurser, der konstituerer måden vi iagttager folkebiblioteket med.

Niels D. Lund skriver om historie, første del med fokus på folkebibliotekets rolle som hukommelses- 
institution i forhold til begreber som kulturarv og historiekultur. Dette indebærer historiebevidsthed, dvs. sammenhængen mellem fortolkningen af fortiden, forståelsen af nutiden og forventningen om fremtiden. Anden halvdel af artiklen er en gennemgang af de forskellige historiske vinkler, der kan lægges på BDI-området, nemlig bibliotekshistorie, videns- og videnskabshistorie, videns- og informationsorganisationens historie samt bog- og mediehistorie.

\section{Vurdering}

Kvaliteten i de enkelte bidrag er gennemgående god. Der er tale om et højt fagligt niveau, med gode og interessante eksemplificeringer. Enkelte bidrag lider dog under at ville nå omkring for meget på den korte plads, der er til rådighed. Det gør, at man ikke kommer til bunds i forklaringerne af begreberne, men i stedet bliver kastet fra det ene nye begreb til det næste, uden at have fornemmelsen af, at man er ved at få styr på teoriområdet. Det får enkelte af bidragene til at virke lidt rodede.

Tre afsnit fremstår som særligt gode. Det drejer sig om Jack Andersens tekst om genreteori og retorik, Hans Dam Christensens bidrag om billedteori samt afsnittet om Foucault af Laura Skouvig. Fælles for de tre er, at de formår at fremstille de respektive teo- rikomplekser på en måde, der forener kompleksitetsreduktion med et bredt overblik og gode eksempler, der gør teorierne levende og forståelige for læseren.

En enkelt detalje, der trækker ned, er, at litteraturhenvisningerne og -listerne er præget af mindre fejl som slåfejl, stavefejl og enkelte forglemmelser. Det er ikke nogen stor ting, men emnet taget i betragtning kunne man med fordel have gået dem efter en ekstra gang.

Selvom titlen på bogen er At forstå biblioteket er fokus alene på folkebiblioteket. Dette er der naturligvis ikke i sig selv noget galt i. Herfra skal dog lyde en opfordring til, at bidragyderne giver sig i kast med at lade deres teorier møde andre dele af det brede bibliotekariske felt. Enkelte er oplagte, fx kan meget af arbejdet med elektronisk sags- og dokumenthåndtering beriges med analyser af den bevidsthed om organisationens historie, det er nødvendigt at være $\mathrm{i}$ besiddelse af, når man fx skal udfærdige politikker omkring bevaring af dokumenter. Et andet eksempel kunne være det sociologiske blik på fag- og forskningsbibliotekerne, der givet ville have nogle ting tilfælles med folkebiblioteksområdet, men som på andre måder ville adskille sig radikalt. 